\title{
Implementation of Tourism Information System at Tuban Regency
}

\author{
Author \\ Anggia Kalista, Agus Wardhono, Argya Drestanta \\ Correspondence \\ Universitas PGRI Ronggolawe Tuban \\ anggiakalista@unirow.ac.id, aguswardhono@unirow.ac.id, adrestanta6@gmail.com
}

\begin{abstract}
:
Republic of Indonesia The Ministry of Communication and Information Technology in Tuban Regency in managing tourism sector is still minimal because it still displays a less attractive website to attract travelers when they want to vacation in Tuban Regency. The purpose of this program is to develop the Tuban Regency Tourism system by using website because this can make it easier for people who really need it in finding tourism objects in Tuban.

We used an observation as the first instrument by observing Tuban regency from many sides, interviewed some tourists which visited Tuban more than once, and read some articles from journals and books.

The role of Communication and Information Technology Department in Tuban Regency is a key to success in Tuban Smart City in 2021. Tuban as City Smart, making integrated applications in both the tourism sector and other parts, this activity has become increasingly important in order to meet the twenty-first century which is all digital.
\end{abstract}

Keywords: implementation, information system, tourism

\section{Introduction}

In this era globalisastion we as part of the world need an information system to connect one each other. Boell (2015) claimed Information systems (IS) involve a variety of information technologies (IT) such as computers, software, databases, commu-nication systems, the Internet, mobile devices and much more, to perform specific tasks, interact with and inform various actors in different organizational or social contexts. Of general interest to the field of IS are therefore all aspects of the development, deployment, implementation, use and impact of IS in organizations and society.

In this program we operated XAMPP stands for Cross-Platform (X), Apache (A), MySQL (M), PHP (P) and Perl (P). It is a simple, lightweighted Apache server that makes it extremely easy for developers to create a local http server with just few clicks.

In the next step we operate by using Sublime Text. That is an editor application for code and text that can run on various operating system platforms using Python API technology. The creation of this application was inspired by the Vim application. This application is very flexible and powerful. The functionality of this application can be developed using sublime-packages. Sublime
Received: 07 Agustus 2019. Accepted: 24 Agustus 2019

Text is not an open source application, which means that this application requires a license that must be purchased. However, several development features of the packages of this application are the result of the findings and receive full support from the community and have a free application license (Haughee, 2013)

We should manage all data in computer system in a big storage. The database is a collection of data stored by a system that can be changed and manipulated through software (application programs) to be processed into information. The form of data management is intended so that access to data can be done easily. The system intended to handle databases is usually called a DBMS (Database Management System).

PHP is a script language and interpreter that is freely available and used primarily on Linux Web servers. PHP, originally derived from Personal Home Page Tools, now stands for PHP: Hypertext Preprocessor, which the PHP FAQ describes as a "recursive acronym."

MySQL is one of the database management systems (DBMS) of many DBMS such as Oracle, MS SQL, Postagre SQL, and others". MySQL functions to process databases using SQL language. MySQL is open source so we can use it for free. 
CodeIgniter is an open application in the form of a PHP framework with an MVC model (Model, View, Controller) to build dynamic websites using PHP. Codeigniter makes it easy for developers to create web applications easily compared to making them from scratch.

\section{Method}

Method of implementation of this program we use literature method by reading some books, looking for journal, and practising theory in a reality work. Interview method held in the field between the authors and the department by guiding of the field supervisor. Research is not a machine to grind out facts. The main machine in all research is a researcher, or a team of researchers by using technology (Stake, 2010: 36).

\section{Time and Place}

Practical Work is carried out at the Communication and Information Technology Agency of Tuban Regency, located on Jalan Mastrip Tuban. Implementation of practical work starts from January 20, 2018 to February 20, 2018. It started on Mondays to Fridays. It began at 8: $30 \mathrm{am}$ to $15: 00 \mathrm{am}$.

\section{Implementation}

\section{Preparation}

We conducted all preparation before building a tourism information system Tuban Regency, the applications needed include:

1. Install Xampp, because this tourism information system can only be accessed offline for a while and we will create a local server.

2. Install Sublime, this system will be built with a PHP program. Use Sublime to build or edit the tourism information system source code.

\section{Pseudocode Program}

In the Pseudocode stage, this program will explain the program to build a Tourism Information System in Tuban Regency.

In the Information System of Tuban Regency Tourism we have made two modules, namely admin and user modules on this system, users can access the views that we provide, namely the user and admin modules, we have also provided module for the admin to help his activity. 1. Database System
Pseudocode:

Begin

Do Show Home Menu

Get Options

Do Case

Case selection $1=1$ do Show Home Menu

Case selection $2=2$ do Show Profile

Case selection $3=3$ do Show Location

Case choice $4=4$ do Show News

Case choice $5=5$ do show comments

End case

End

2. Profile

Pseudocode:

Begin

Do Show Profile Menu

Get Options

Get Profile Data

Do Case

Case selection $1=1$ do Show Home Menu

Case selection $2=2$ do Show Profile

Case selection $3=3$ do Show Location

Case choice $4=4$ do Show News

Case choice $5=5$ do show comments

End case

End

\section{Location}

Pseudocode:

Begin

Do Show Location Menu

Get Options

Get DataLocation

Do Case

Case selection $1=1$ do Show Home Menu

Case selection $2=2$ do Show Profile

Case selection $3=3$ do Show Location

Case choice $4=4$ do Show News

Case choice $5=5$ do show comments

End case

End

\section{News}

Pseudocode:

Begin

Do Show News

Get Options

Get DataBerita

Do Case 
Case selection $1=1$ do Show Home Menu

Case selection $2=2$ do Show Profile

Case selection $3=3$ do Show Location

Case choice $4=4$ do Show News

Case choice $5=5$ do show comments

End case

End

\section{Comments}

Pseudocode:

Begin

Do Show Comments

Get Options

Get DataComment

\section{Do Case}

Case selection $1=1$ do Show Home Menu

Case selection $2=2$ do Show Profile

Case selection $3=3$ do Show Location

Case choice $4=4$ do Show News

Case choice $5=5$ do show comments

End case

End

6. Web Admin

Pseudocode:

\section{Begin}

Do Show Web Admin

UserAdmin entry

Read DataAdmin

End

7. Dashboard

Pseudocode:

Begin

Display Dashboard Menu

Get Maps

End

8. Profile

Pseudocode:

Begin

Profile display form

Entry Title Profile

Entry IsiBerita

Save To Profile Data

End

9. Add Location

Pseudocode:

Begin
Display form Add Location

Read Category

Namahotel Entry

Entry Category

Entry Address

Telephone Entry

Entry Latitude

Longlitud Entry

Save To Location Data

End

10. Register Location

Pseudocode:

Begin

Display Location List Form

Read DataLocation

End

11. Categories

Pseudocode:

Begin

Category display form

Read Category

Location Location Entry

Information Entry

Entry Icon

Save To Category Data

End

12. Add News

Pseudocde

Begin

Display form Add News

Entry Title

Entry IsiBerita

Image Entry

end

13. Register News

Pseudocode:

Begin

Display the News List form

Read News List

end

14. Comments

Pseudocode:

Begin

Display the News List form

Read News List 
End

\section{Login admin}

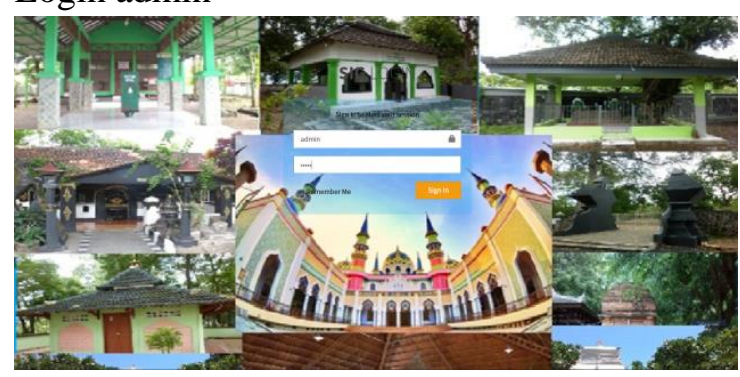

Figure 1 Login admin

Display to log in to admin
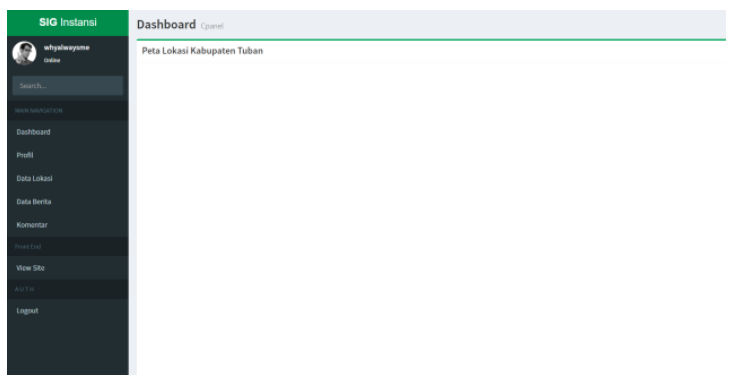

Figure 2 Admin dashboard

This displays the admin dashboard to see the map we want to add.

Display of Admin Profile
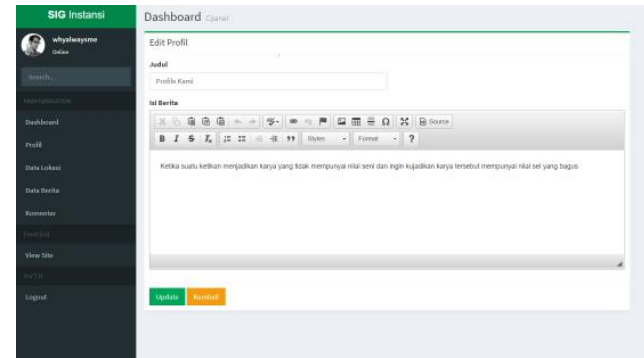

Figure 3 Admin Profile Page

This view To edit the profile on the profile page

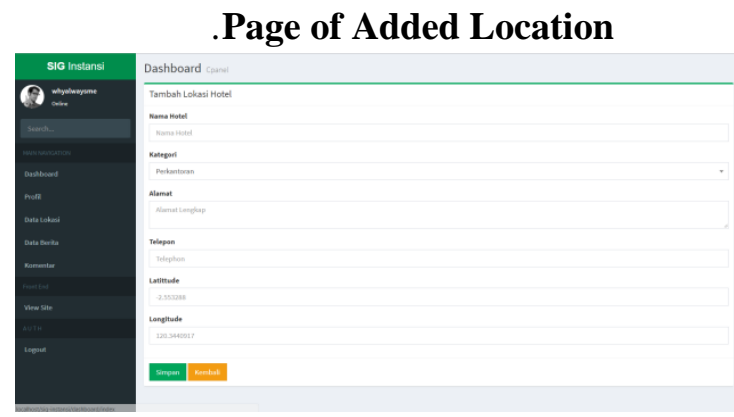

Figure 4 Page Add Location

Page to add location to google maps.
List of Location

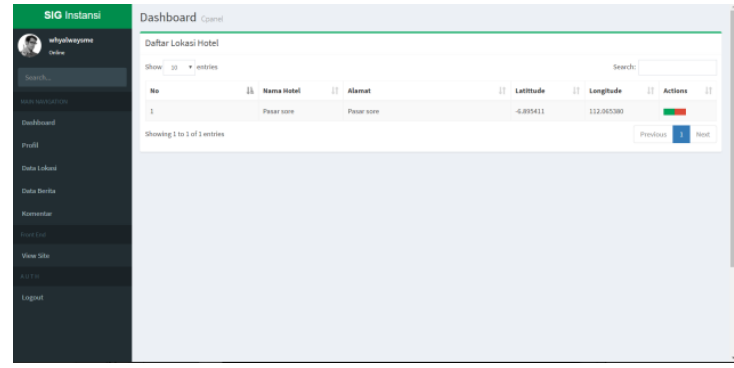

Figure 5 Location List Page

To see a list of locations on google maps.

\section{Tambah Berita}

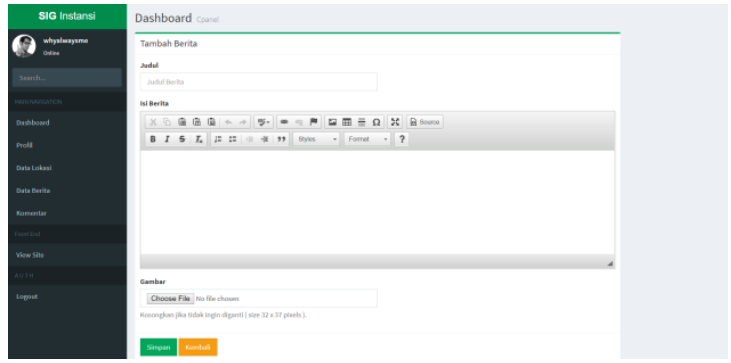

Figure 6 Add News Page

Menu for adding news.

\section{List of News}

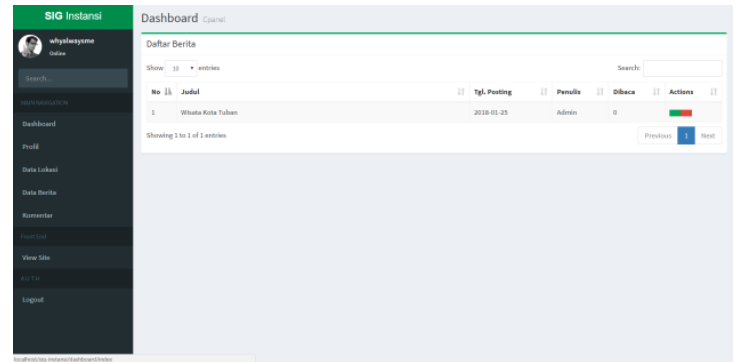

Figure 7 News List Page

To see a complete list of news.

Admin Comment Page

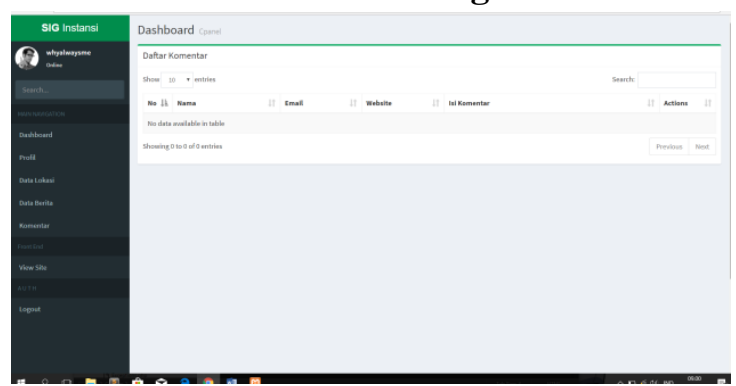

Figure 8 Admin Comment Page

Comment management page on the system.

\section{Home Page}




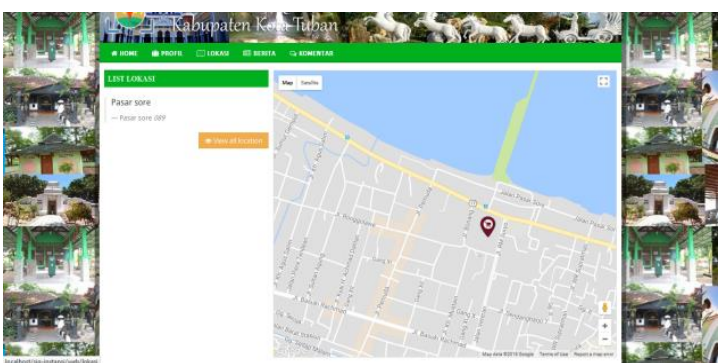

Figure 9. Home page

Above is the Home or the initial appearance of the system created.

Halaman Profil

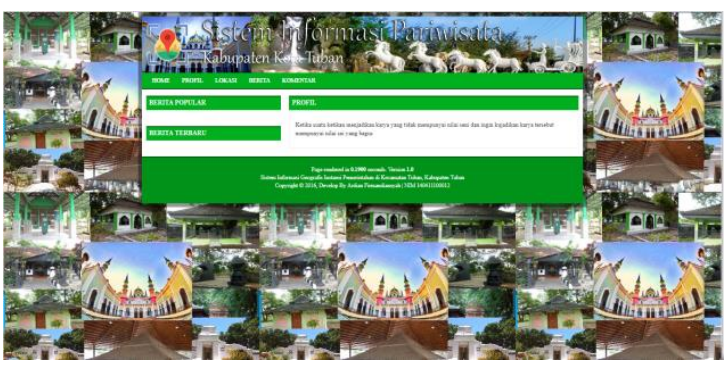

Figure 10. Profile page

In the profile menu there are contents from the profile.

Halaman Lokasi

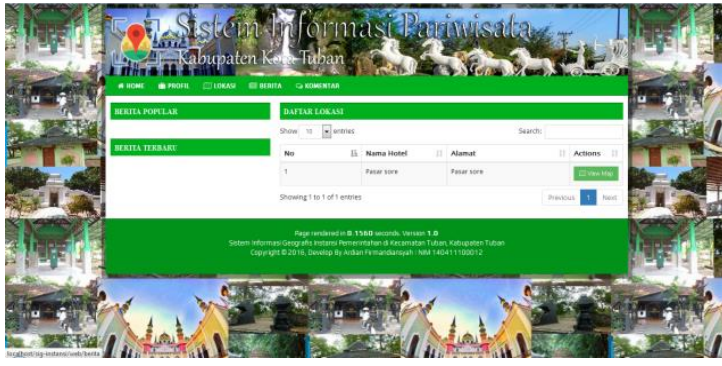

Figure 11. Location page

Login contains the username and password that must be entered.

Halaman Berita

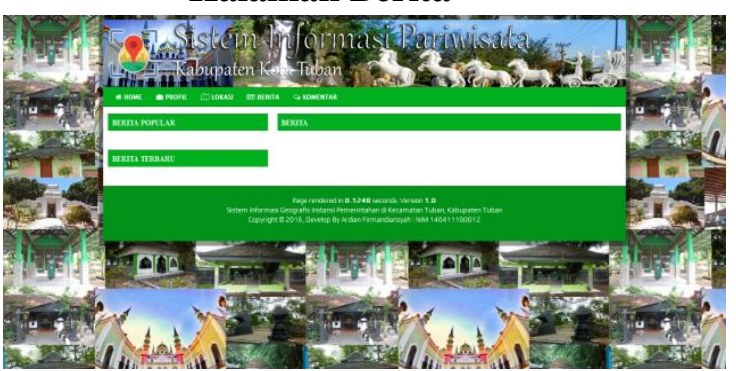

Figure 12. News page

Figure 12 A news page is a display on the page that will contain the latest news.

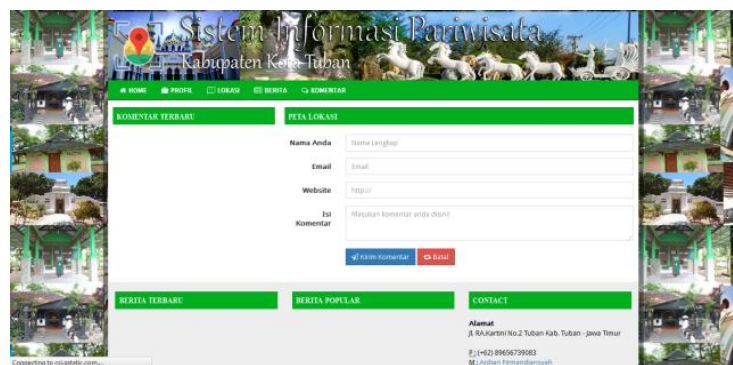

Figure 13. Comments page

The page for us to fill with comments or criticism for tourist attractions

\section{Database Sistem Informasi}

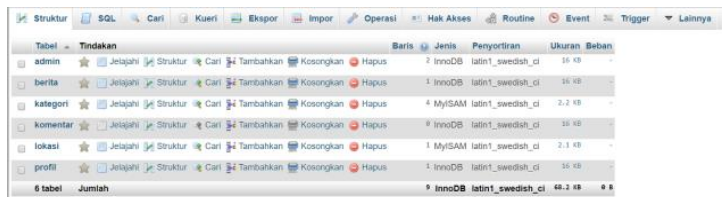

Figure 14 Information System Database

Database Information System stores several tables, namely: admin, news, categories, comments, location, and profile.

\section{Tabel Admin}

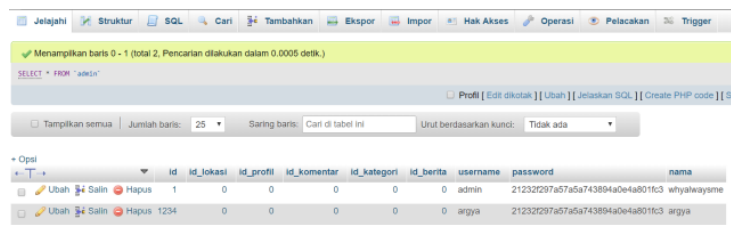

Figure 15 Admin Table

Admin table has a structure, namely: Id, Id_location, Id_profil, Id_Comentar, Id_category, Id_ita, username, password and name.

\section{Tabel Berita}

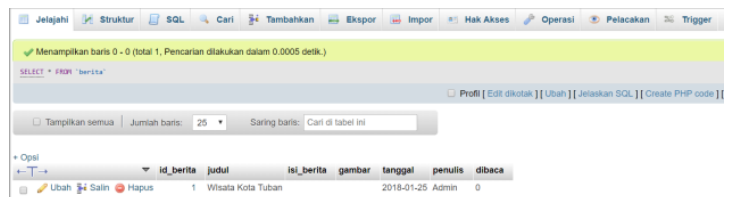

Figure 16 News Table

The News table has a structure, namely: Id_itita, title, isi_berita, image, date, author, and read. 
Tabel Kategori

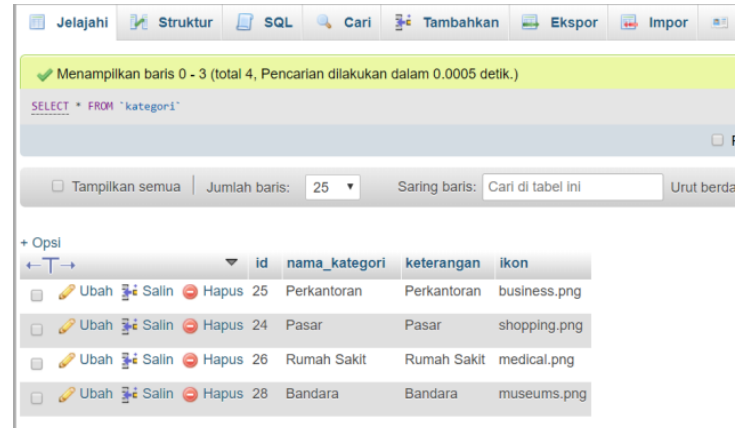

Figure 17 Table of Categories

The Category table has a structure, namely: $i d$, name_category, description, and icon.

\section{Comment table}

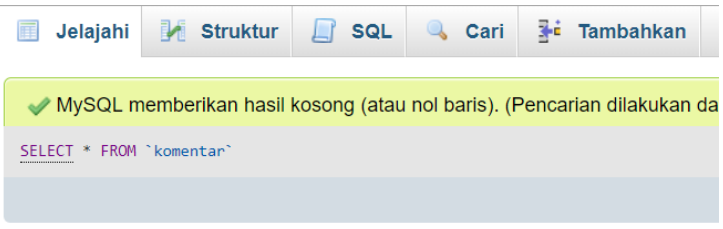

id_komentar nama email website komentar

Figure 18 Table of Comments

The comments table has a structure, namely: id_comments, names, emails, websites, and comments.

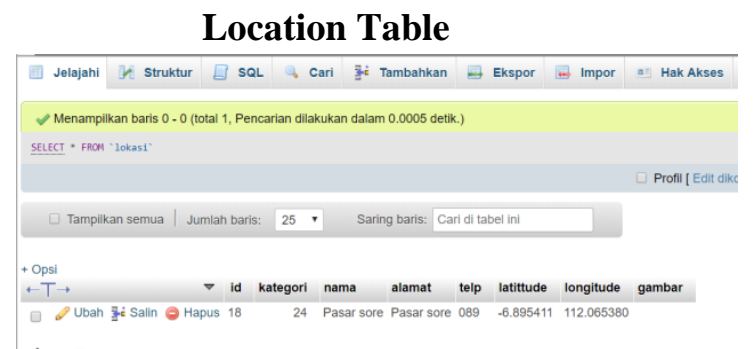

Figure 19 Location Table

The location table has a structure, namely: id, category, name, address, telephone, latitude, longtitude, and image.

\section{Profile Table}

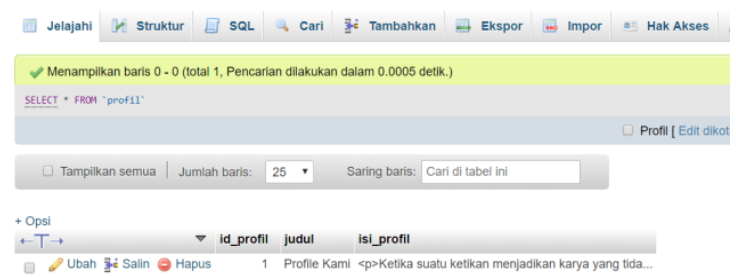

Figure 20 Profile Table

The profile table has a structure, namely: id_profil, title, and isi_profil.

\section{Result And Discussion}

Making tourism information system in Tuban Regency so that tourists can easily find tourist attractions is the main goal of this program. We make evaluations of the achievement of the competency of this programming application by implementing an integrated module including assessing the ability to identify problems, define problems, prepare systems, profiles, locations, news, comments, web admins, dashboards, profiles, add locations, list locations, categories, added the news, the list of news was arranged systematically. The next step is how to organize it so that the program can be implemented, what should be done if something different happens from the original plan, and the ability to solve problems with different conditions is something that has been thought before.

Some of the things that are supporting factors in this service activity include: (1) all staff and leaders are very enthusiastic in providing the information needed, this is because the making of this program has the potential to be developed at the level of practical application in the field, both now and the time will come. Besides that, this programming is the substance of learning which is quite potential to be developed with special applications of automatic and integrated systems; (2) along with the preparation period of Tuban as City Smart, making integrated applications in both the tourism sector and other parts, this activity has become increasingly important in order to meet the twenty-first century which is all digital.

\section{CONLUSION}

The world is always changing, and new technology is being develop. Due to this, each generation is unique and adapts to technology in different ways. In the digital era most of the people uses Internet to communicate one each other. They always look for something new, tourism object is one of some Tuban Regency programs have been developing recently. Sooner or later the application to make it easier for tourists in finding tourist destinations is very necessary.

This can be done if the formulation of policies in the fields of tourism, culture, youth and sports is carried out in an orderly, good and systematic manner. It must be integrated in Smart city program as a part program of Republic of 
Indonesia the Ministry of Communication and Information Technology in Tuban Regency.

\section{References:}

Anhar, 2010. Panduan Menguasai PHP dan MySQL Secara Otodidak. Jakarta: Mediakita.

Boell, Sebastian K. \& Kecmanovic Dubravka Cecez- 2015. What is information System. DOI: $\quad 10.1109 /$ HICSS.2015.587 https://www.researchgate.net/publication/271 588444_What_is_an_Information_System.

Haughee, Eric. 2013. Instant Sublime Text Starter. Birmingham: Packt Publishing Ltd

Oktavian, Diar Puji. 2010. Menjadi Programmer Jempolan Menggunakan PHP. Yogyakarta: Mediakom.

Stake, Robert. 2010. Qualitative Research Studying How Things Work. New York: The Guilford Press. 